\title{
Retracted: Uji Organoleptik Boba Substitusi Tepung Biji Labu Kuning Tinggi Serat dan Protein
}

\author{
Maurizka Sabrina Septia, Supriyadi*, Septa Katmawanti \\ Universitas Negeri Malang, Jl. Semarang No. 5 Malang, Jawa Timur, Indonesia \\ *Penulis korespondensi, Surel: supriyadi.fik@um.ac.id
}

Paper received: 23-7-2021; revised: 13-8-2021; accepted: 20-8-2021

Abstract
This paper has been withdrawn at the request of the author and has been retracted. 